\title{
押し引き両荷重に対し同等の 性能を発揮する片筋違いの開発 \\ IMPROVEMENT OF SINGLE-BRACED SHEAR WALL SYSTEM HAVING SAME PERFORMANCE FOR PUSH AND PULL LOAD
}

\section{村上了一 $* 1$ 王岡富彦——2 \\ 門脇秀伸 - $* 3$ 小松幸平}

キーワード :

筋違い，LVL，木ねじ，壁倍率

Keywords:

Brace, LVL, Wood screw, Shear wall factor

\section{Satoru MURAKAMI \\ Tomihiko TAMAOKA - $* 2$ Hidenobu KADOWAKI — $* 3$ Kohei KOMATSU $* 4$}

The objective of this research is to realize a single-braced shear wall system, which has same performance when the diagonal brace is subjected to compression and tension. To improve performance in brace joint, a new LVL product made of alternately laminating rubber wood and falcate wood was introduced and wood screws which have high shear resistance were used for them. Then developed brace system was investigated to confirm its shear performance in both loading directions. Consequently, improved shear wall had 3.5 at compression and 3.8 at tension in the shear resistance factor.
1. はじめに

在来軸組構法において、筋違い耐力壁はよく使用される耐震要素 の一つである。この筋違い耐力壁は建築基準法施行令 46 条で「筋か いを入れた軸組を釣合い良く配置しなければならない」と指示され ており、実際の施工では片筋違い耐力壁を八の字型に配置するか、 若しくは筋違いをたすき掛けに配置しなくてはならない。これは、 片筋違い耐力壁の筋違い材に引張荷重が作用寸る時の性能と、圧縮 荷重が作用寸る時の性能とが大きく異なるためである。しかし、八 の字型に筋違い耐力壁を配置することは、2P(壁長 $1820 \mathrm{~mm}$ )以上の 空間が必要となり、設計条件によっては困難な場合がある。また、 筋違いをたすき掛けにすることも、施工上不便な場合がありうる。 たとえ片筋違いであっても筋違いが圧縮、引張に対して同等の耐力 性能を発揮できるものが開発できれば、特に外部からの施工が難し いとされる隣地との間隙が狭い住宅の耐力壁や、一般建築物の室内 耐力壁等には、このような正負均等な性能を有する片筋違い耐力壁 が有効であると考えられる。

片筋違い耐力壁の筋違い材に引張荷重が作用寸る場合と圧縮荷重 が作用する場合に性能が異なる理由は、それぞれ荷重に対する抵抗 要素と抵抗機構が異なるためである。引張荷重が作用寸る場合は筋 違い材と横架材とを緊結する接合具のせん断抵抗によって抵抗する のに対し、圧縮荷重が作用寸る場合は筋違い突きつけ部の圧縮によ って抵抗する。また終局耐力の低下は、引張荷重が作用する場合、 筋違い端部の木部破壊によるのに対し、圧縮荷重が作用寸る場合は 筋違い材の座屈破壊によって耐力の低下が生じる。一般的には、筋 違い材に引張荷重が作用する時の性能は圧縮荷重が作用寸る時の性 能より劣る。しかし、その原因となっている筋違い端部の接合につ いて、国土交通省告示 1460 条では既往の筋違い接合部の仕様を提示 するだけで、特に具体的な必要性能については規定していない。

そこで、本研究では断面 $45 \times 90 \mathrm{~mm}$ の筋違い材に圧縮荷重が作用 する時と引張荷重が作用する時と同等の性質を示し、かつ合板耐力
壁を上回る壁倍率 3.0 以上の高い性能を有するべく片筋違い耐力壁 の改良を目的とし、特に筋違い接合部性能向上を目指した開発研究 を行った。断面 $45 \times 90 \mathrm{~mm}$ の筋違いの端部における仕口は、金物と 木㸚じにより構成されることが一般的である。そこで、次の 2 点の 改良を行った。1つ目は筋違い材に力学的性能のばらつきが少ない、 エンジニアード・ウッドである LVLを用いた。2つ目に径が大きく せん断耐力の高い木ねじを新たに作製した。これらの改良を評価す るため、筇違い材の力学性能試験と木ねじの鋼板添え板一面せん断 試験を行い木ねじ一本あたりのせん断耐力を求めた。この結果から 壁倍率 3.0 の性能を発揮するのに必要な木ねじ本数を定めて筋違い 耐力壁を設計し、最終的に、設耐力壁の実大試験を行い、設計方針 の妥当性を検証した。

\section{2. 試験}

\section{1 筋違い材の力学性能}

本研究では筋違い材にラバーウッド/ファルカータ異樹種 $\mathrm{LVL}^{1)}$ 用いた。ラバーウッド(Hevea brasilience)は天然ゴムを生産するプラ ンテーションにおいて、ゴムの取れなくなった材である。材として の特徴は比較的高密度、高強度な一方、乾燥によるねじれが生じや 寸く脆性的に壊れる欠点がある。ファルカータ (Paraserianthes falcataria)はマレーシアやインドネシアで広く栽培されている早生 樹である。特徴として多孔質であり低密度、加工しやすいが比較的 強度が小さい。この 2 種類の樹種を交互に積層することにより、こ の異樹種 LVL は適度な強度、加工性を持つ ${ }^{2)}$ 。

LVL である点から、この異樹種 LVL は製材と比べ節や目切れなど の影響が少なく、力学性能においてもばらつきが少ない。この性能 が筋違い端部の性能のばらつきを少なくし、結果その耐力を高く見 積もることができると考えた。また、ラバーウッドとファルカータ はどちらの材も交錯木理を持つ。この交錯木理をもつ樹種同士を交 互に積層寸ることにより、瀻維が層ごとに交錯した状態で積層され

\footnotetext{
京都大学生存圈研究所博士課程 修士 (農学)

(干611-0011 宇治市五ヶ庄木質ホール 2F)

タカヤマ金属工業(㑣研究室 室長

㹯コクブ営業課 主任

京都大学生存圈研究所 教授・農博
}

\footnotetext{
Graduate Student, Research Institute for Sustainable Humanosphere, Kyoto Univ., M. Agr.

Chief of research dept., Takayama Metal Industrial Corporation

Chief of business dept., Kokubu Corporation

Prof., Research Institute for Sustainable Humanosphere, Kyoto Univ., Dr. Agr.
} 
ると考えられる。この交錯積層には材自身の割裂の発生を抑制する 効果 ${ }^{3)}$ があるため(図 1)、筋違い端部の性能を高めるものと考えた。 この異樹種 LVL の力学的性能を相対的に評価するため、現在筋違 い材として一般的に利用されているべイマツ製材(Pseudotsuga menziesii)をコントロール材として動的ヤング係数・曲げヤング係 数・曲げ強度・世九断強度及び面圧性能に於いて比較を行った。断 面 45×105mm、長さ $3000 \mathrm{~mm}$ の LVL160 体、ベイマツ 80 体を縦振動 法により動的ヤング率を測定した。また同材に対してスパン $1000 \mathrm{~mm}$ でフラットワイズの中央集中載荷実験をそれぞれ 10 体ずつ 行い、曲げヤング率、曲げ強度を算定した。また JIS の規格 ${ }^{4)}$ に基 づくブロックせん断試験を行い、せん断強度の測定を行った(図 2)。 年輪または積層面に対するせん断破壊面の方向をパラメータとした が、異樹種 LVLに関しては積層方向に対し破壊面が垂直なものを $\mathrm{R} 、$ 平行なものを $\mathrm{T}$ とし、各条件 15 体につき試験を行った。さらに直 径 $4.4 \mathrm{~mm}$ の円形断面鋼棒を図 3 に示寸ように軸が年輪・積層面に対 し直交する方向に設置し、繊維方向に加力することで、部材の面圧 特性を把握した。鋼棒をめり込ませる箇所にはあらかじめ径 $4.5 \mathrm{~mm}$ の半円を設け、その他の条件は ASTM の規準に基づいた ${ }^{5)}$ 。

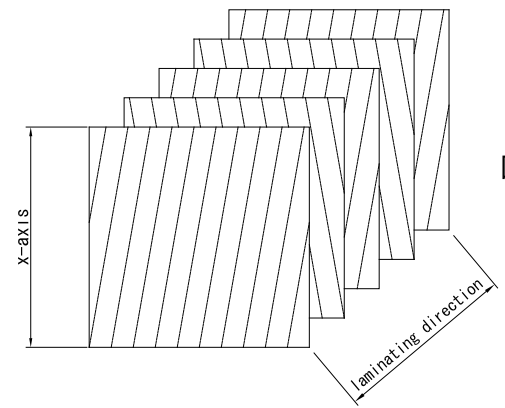

図 1 交錯積層された単板積層材
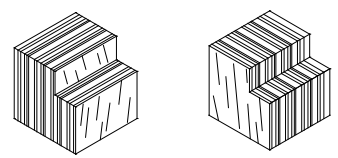

図 2 異樹種 LVL せん断試験体 （左：T方向、右：R 方向）

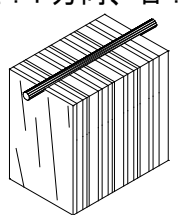

図 3 面圧試験体

\section{2 木ねじの鋼板添え板一面せん断試験}

異樹種 LVLを筋違い材として用いた時の木ねじ 1 本あたりのせん 断耐力を把握するために、鋼板を添え板とした一面せん断試験を行 った。図 4 に木ねじの形状を、図 5 に試験体概要を示す。試験では 主材一鋼板間の初期摩擦をできる限り小さくするため、鋼板が自由 回転するくらいの隙間を設けた。また主材一鋼板間に厚さ $0.1 \mathrm{~mm}$ の テフロンシート(ポリテトラフルオロエチレンシート)を挟み、ロー プ効果 ${ }^{6)}$ にる二次的摩擦の影響を小さくするよう配慮した。図 6 に示すように木ねじは単板の積層方向に対し垂直に挿入し、繊維方

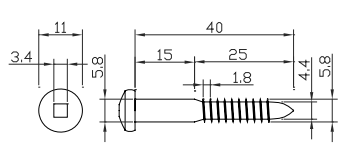

図 4 木ねじの形状

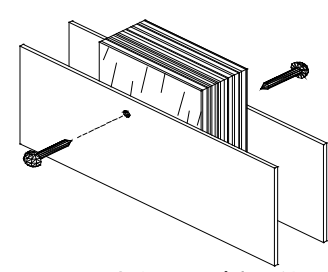

図 6 木ねじの挿入位置

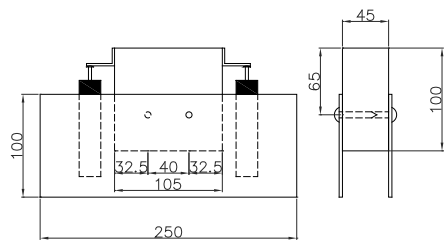

図 5 一面せん断試験体図

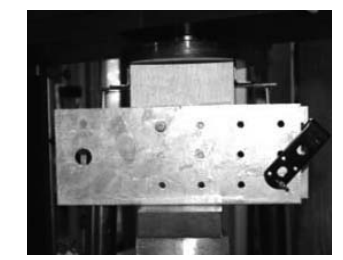

写真 1 一面せん断試験の様子
向に速度 $2 \mathrm{~mm} / \mathrm{min}$ で加力した。木礼じの形状は、1 本あたりのせん 断耐力が高くなるよう、通常の木ねじより太短い径長比が約 8 の木 ねじを作製した。用いた線材は $\mathrm{SWRCH} 22 \mathrm{~A}^{7)}$ 、熱処理は光輝焼き入 れ、低温焼き戻しを行った ${ }^{8)}$ 。有効径は Eurocode $5^{9)}$ の定義に従って、 ネジ部谷径の 1.1 倍 $(4.84 \mathrm{~mm})$ とした。この時、先孔径も同様に Eurocode 5 の定義に従って、円筒部の 0.70 倍 $(4.06 \mathrm{~mm})$ 程度、直径 $4 \mathrm{~mm}$ とした。

木質構造設計規準・同解説 ${ }^{10)}$ によれば、JIS 規格の木ねじを挿入 するにあたり、材の割裂を防ぐために先孔を設けるよう規定してい るが、一般的に実際の建築現場では木ねじを使用するとき、手間の 面から先孔を設けずに打ち込まれることがある。また現状として、 建築物に木ねじを使用するとき、その全てにおいて先孔を設けて木 ねじを挿入することは現実的とは考えられない。これを踏まえ、先 孔の有無がせん断性能に及ぼす影響に対し検討を行った。また前項 と同様、LVLとベイマツ製材を主材とした場合とを比較した。よっ て試験は異樹種 LVLの先孔を設けた場合と設けない場合、ベイマツ 製材の先孔を設けた場合と設けない場合の、計 4 条件につき各 5 体 ずつ行った。

\section{3 片筋違い耐力壁試験}

笳違い耐力壁の性能を確認するため、長さ $910 \mathrm{~mm}$ 、高さ $2730 \mathrm{~mm}$ の試験体を作製して柱脚固定式、見かけのせん断変形角を基準とし た静的正負繰り返し水平加力実験を行った(図 7)。試験における見か けのせん断変形角は梁材の水平方向変位(図 7 : 変位計\#1)を試験体せ いで除した值を用いた。柱、土台、梁にはスプルース集成材を用い、 短期許容引張耐力が $35 \mathrm{kN}$ のホールドダウン金物を軸組の四隅に取 り付けた。

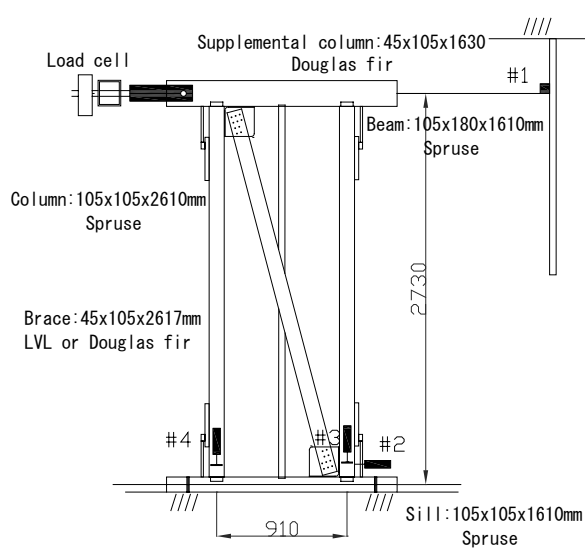

図 7 耐力壁試験体図

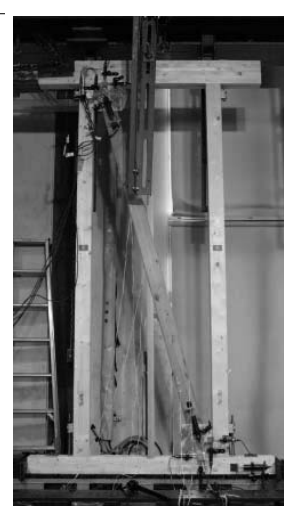

写真 2 耐力壁試験の

筋違い材は異樹種 LVL とベイマツ製材(45mm x 105mm x 2617mm) を用いた。筋違いの座屈破壊を遅らせるために 2 つの柱の中央にベ イマツ製材の間柱 $(45 \mathrm{~mm}$ x $105 \mathrm{~mm}$ x 2610mm)を設けた。間柱は中央 をかき込み、首下長さ $90 \mathrm{~mm}$ のビス 2 本によって筋違い材に留めつ けた。フレームと間柱の両端との取り付けは CN90 を斜めに 2 本打 ち付けた。

筋違い端部の接合金物は、より多数本の木ねじで笳違い材を柱一 横架材に緊結するよう新たに設計した。図 8 にその形状と、柱一土 台への取り付けを示した。木礼じ接合が降伏するまでビス穴近辺で 金物自身の面圧降伏が生じないよう、その厚みは $3.2 \mathrm{~mm}$ とした。 


\begin{tabular}{|c|c|c|c|c|c|c|c|c|}
\hline & $\begin{array}{l}\text { Density } \\
\left(\mathrm{kg} / \mathrm{m}^{3}\right)\end{array}$ & $\begin{array}{c}\mathrm{MOE}_{\mathrm{d}} \\
\left(\mathrm{kN} / \mathrm{mm}^{2}\right)\end{array}$ & $\begin{array}{c}\mathrm{MOE}_{\mathrm{b}} \\
\left(\mathrm{kN} / \mathrm{mm}^{2}\right)\end{array}$ & $\begin{array}{c}\mathrm{MOR} \\
\left(\mathrm{N} / \mathrm{mm}^{2}\right)\end{array}$ & \multicolumn{2}{|c|}{ Shear Strength(N/mm²) } & $\begin{array}{c}\text { Bearing Strength } \\
\left(\mathrm{N} / \mathrm{mm}^{2}\right)\end{array}$ \\
\hline \multirow{3}{*}{ LVL } & Ave. & 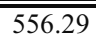 & 10.10 & 8.38 & $\overline{52.63}$ & $\overline{\overline{6.46}}$ & $\overline{8.46}$ & 33.07 \\
\hline & C.V.(\%) & 1.44 & 3.09 & 8.90 & 6.63 & 27.76 & 13.87 & 5.17 \\
\hline & E.V. & & 10.08 & 8.22 & 38.67 & 2.99 & 6.20 & 29.07 \\
\hline \multirow{3}{*}{ Douglas Fir } & Ave. & 501.59 & 13.46 & 9.97 & 54.05 & 7.99 & 9.14 & 39.70 \\
\hline & C.V.(\%) & 10.03 & 20.70 & 21.47 & 19.30 & 17.97 & 21.27 & 11.01 \\
\hline & E.V. & & 13.22 & 9.50 & 13.46 & 5.13 & 5.27 & 29.49 \\
\hline
\end{tabular}

(注) $\mathrm{MOE}_{\mathrm{d}}$ : 動的ヤング係数, $\mathrm{MOE}_{\mathrm{b}}$ : 曲げヤング係数, Ave.: 平均值, C.V.: 変動係数, E.V.: 下限值

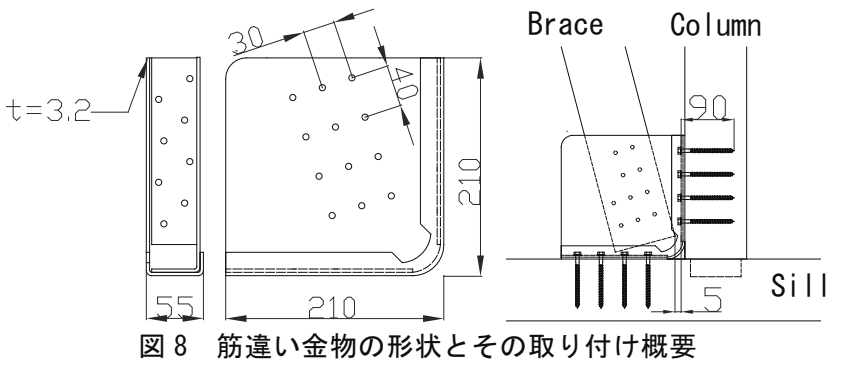

図 8 で示すように金物と柱一横架材の留めつけは首下長さ $90 \mathrm{~mm}$ の木ねじで行ったが、その本数は筋違いに壁倍率 3.0 に相当する軸 力が生じることを想定し、金物と柱一横架材の接合部が降伏せぬよ う決定した。なお小ねじのせん断耐力と引き抜き耐力は木質構造設 計基準・同解説に準じてそれらの值を求め ${ }^{10)}$ 、結果として柱一横架 材にそれぞれ 8 本ずつ打ち付けた。金物と筋違い材を留めつける木 ねじの本数は 10 本とした。この本数の決定については 3 章において 述べる。筋違い材に圧縮荷重が作用する場合と引張荷重が作用する 場合とで耐力壁が同等の性能を持つように、筋違い端部とフレーム との間に $5 \mathrm{~mm}$ の隙間を設けた。これは $1 / 60 \mathrm{rad}$. 変形する時までの初 期段階で筋違いとフレームとが接触せず、筋違いの耐力が木ねじの 抵抗のみによって発現することを目的としたものである。

正負交番繰返し加力の履歴は、見かけのせん断変形角で $\pm 1 / 300$, $\pm 1 / 200, \pm 1 / 150, \pm 1 / 100, \pm 1 / 60, \pm 1 / 30, \pm 1 / 15$ (rad.) とし、その他の試験 条件は木造軸組工法住宅の許容応力度設計 ${ }^{11)}$ に従った。筋違いが圧 縮力を受けて加力が終了寸る試験体と、引張力を受けて加力で終了 する試験体をそれぞれ 3 体ずつ、計 12 体について試験を行った。

\section{3. 結果と考察}

\section{1 筋違い材の力学性能}

表 1 に筋違い材の各種力学的性能を示す。ヤング係数の下限值は 信頼性水準 75\%の 50\%下側許容限界を、強度の下限值は信頼性水準 $75 \%$ の $95 \%$ 下側許容限界を示す。密度は異樹種 LVL の方がベイマツ 製材に比べ 1 割ほど大きかったものの、動的ヤング係数、曲げヤン グ係数はその平均值、下限值とも異樹種 LVL がベイマツ製材を下回
った。一方、曲げ強度は平均值において異樹種 LVL がベイマツ製材 を下回ったが、下限值ではばらつきの影響が大きく現れ、異樹種 LVL の值がベイマツ製材のそれを大きく上回った。せん断強度に関して、 異樹種 LVL の積層面に対し平行に破断面が生じる時(T)、比重の低 いファルカータの単板が破壊することによってベイマツ製材と比較 してばらつきが大きく、低い下限值を示した。一方、異樹種 LVL の 積層面に垂直に破断面が生じる時(R)、ばらつきが低くベイマツ製材 の下限值を上回った。面圧強度の平均值はベイマツ製材が高かった が、下限值はばらつきの影響により異樹種 LVL とベイマツ製材で同 等の值を示した。

材のせん断試験、面圧試験の結果から、異樹種 LVL の単板の積層 方向に対し垂直に接合具を挿入した時、ばらつきが少なくベイマツ 製材と同じ程度のせん断性能を示すと考えられる。

\section{2 木ねじの一面せん断試験}

図 9 に試験から得られた木ねじ一本あたりの荷重一変位曲線を示 す。この時のすべり係数は荷重一変位曲線において $0.1 P_{\text {max }}$ と $0.4 P_{\text {max }}$ を示す点の傾き、 $P_{y \text {-off }}$ は $0.1 P_{\max }$ と $0.4 P_{\max }$ との接線を有効径で $5 \%$ offset した值と荷重一変位曲線との交点とした ${ }^{10)}$ 。表 2 に各種算 出値をそれぞれ示す。表 2 において $P_{\max }$ と $P_{y \text {-off }}$ は信頼水準 $75 \%$ の

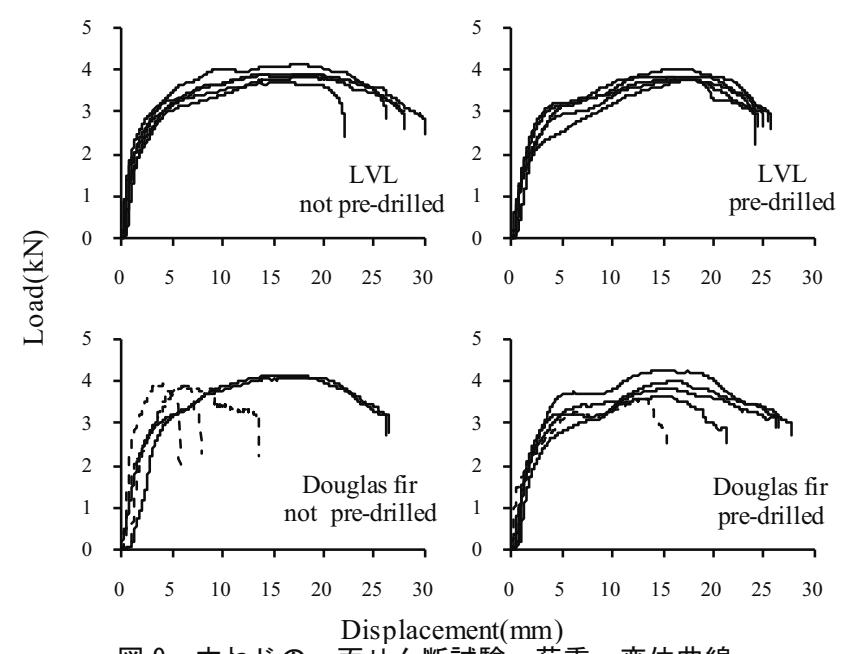

図 9 木ねじの一面せん断試験、荷重一変位曲線

表 2 木ねじ鋼板添え板一面せん断試験結果 : 各種算出値

\begin{tabular}{|cc|ccc|ccc|ccc|c|c|}
\hline & & \multicolumn{3}{|c|}{$P_{\max }(\mathrm{kN})$} & \multicolumn{3}{c|}{$K(\mathrm{kN} / \mathrm{mm})$} & \multicolumn{3}{c|}{$P_{y-\text { off }}(\mathrm{kN})$} & \multicolumn{2}{c|}{$\delta_{u}(\mathrm{~mm})$} \\
& & Ave. & C.V.(\%) & E.V. & Ave. & C.V.(\%) & E.V. & Ave. & C.V.(\%) & E.V. & Ave. & C.V.(\%) \\
\hline \hline \multirow{2}{*}{ LVL } & not pre-dorilled & 3.91 & 4.09 & 3.51 & 2.17 & 8.66 & 2.11 & 2.00 & 6.07 & 1.73 & 26.11 & 9.37 \\
& pre-dorilled & 3.85 & 2.28 & 3.63 & 1.63 & 21.87 & 1.52 & 2.04 & 8.75 & 1.60 & 24.26 & 1.98 \\
\hline \multirow{2}{*}{ Douglas Fir } & not pre-dorilled & 4.00 & 2.51 & 3.75 & 2.33 & 49.11 & 1.95 & 2.41 & 15.43 & 1.49 & 16.10 & 62.62 \\
& pre-dorilled & 3.86 & 7.56 & 3.14 & 1.90 & 24.24 & 1.74 & 1.97 & 11.35 & 1.42 & 22.91 & 19.76 \\
\hline
\end{tabular}

(注) $P_{\max }$ : 最大荷重, $K:$ 寸べり係数, $P_{y-o f f}: 5 \%$ offset 法で求めた降伏荷重, $\delta_{u}$ : 最大荷重経過後、0.8 $P_{\max }$ 荷重低下した点の変位 
表 3 木ねじ鋼板添え板一面せん断試験結果：完全弾塑性モデルにおける耐力算出値 ${ }^{11)}$

\begin{tabular}{|c|cccc|cccc|}
\hline & \multicolumn{3}{|c|}{ LVL } & \multicolumn{4}{c|}{ Douglas fir } \\
& Ave.(kN) & C.V.(\%) & E.V.(kN) & required number & Ave.(kN) & C.V.(\%) & E.V.(kN) & required number \\
\hline \hline$P_{y-B L}$ & 2.20 & 8.75 & 1.73 & 10 & 2.29 & 17.36 & 1.31 & 13 \\
$P_{u} \times\left(0.2 / D_{s}\right)$ & 2.93 & 8.76 & 2.30 & 8 & 1.94 & 9.40 & 1.49 & 12 \\
$2 / 3 P_{\max }$ & 2.60 & 4.13 & 2.34 & 8 & 2.66 & 2.51 & 2.50 & 7 \\
$P_{\text {I/150rad. }}$ & 3.24 & 13.99 & 2.12 & 8 & 2.73 & 31.89 & 0.58 & 30 \\
\hline
\end{tabular}

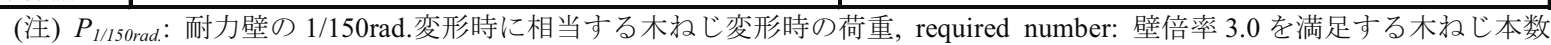

95\%下側許容限界を、 $K$ は信頼水準 75\%の $50 \%$ 下側許容限界を示し た。

$P_{\max } P_{y-o f f}$ において、4 条件の間であまり明確な差は見られなかっ たが、 $P_{y \text {-off }}$ において若干ベイマツ製材にばらつきが高い傾向が見ら れた。また $K$ において異樹種 LVL、ベイマツ製材ともに先孔を空け ていない場合が先孔を空けた場合に比べ高くなる傾向を示した。試 験体の破壊性状として異樹種 LVLには 2 条件ともに割裂破壊が見ら れなかった。一方、ベイマツ製材では先孔なしの場合 5 体中 3 体、 先孔ありの場合で 5 体中 1 体において、主材に割裂破壊が生じた。 図 9 の荷重一変位曲線における点線で示した曲線が割裂を生じた試 験体の曲線である。

交錯積層の効果によって異樹種 LVL は割裂が抑制されたと考え られる。よって異樹種 LVL はこの木㸚じ程度の径をもつ木ねじを用 いる際、先孔を設けずとも、先孔を設けた時と同程度の $P_{\max } 、 P_{y-\text { off }}$ を示し、なおかつ割裂による急激な耐力の低下を生じないと考えら れる。そこで、耐力壁試験では実務での利便性を考慮し、先孔を空 けずに木ねじを挿入することとした。

\section{3 木ねじ本数の算定}

筋違い耐力壁をトラスとして捉え、力の釣合い、変形の適合条件 よりその性能はよく把握できることが知られている ${ }^{12)}$ 。本研究では、 壁倍率 3.0 以上の性能を持つ耐力壁を設計するに当たって、以下の 仮定の下、金物と筋違い端部を緊結する木ねじの本数を決定した。
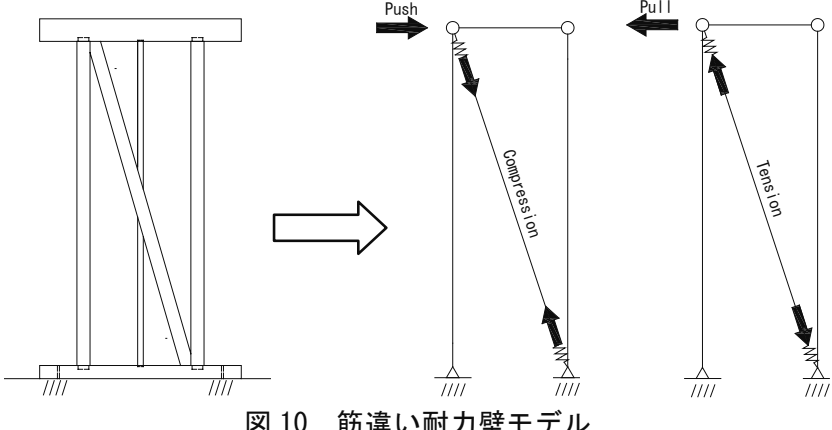

図 10 筋違い耐力壁モデル

(1)筋違い耐力壁は図 10 に示寸ようなトラス構造で、変形後も平行 四辺形を保つ。この時、部材の弾性変形、および柱一横架材節点の めり込み、浮き上がりは筋違い端部の接合の変形に比べ十分小さい と考えられることから、それらの変形を無視し、筋違い接合部の変 形のみ生じるものと寸る。(2)木称じのせん断性能は完全弾塑性体と して振舞うものとする。このときの木㸚じのせん断性能は 2.2 で行 った試験結果を鉛直構面及び水平構面の短期基準せん断耐力の算出 方法に沿って完全弹塑性置換した信頼水準 75\%の 50\%下側許容限界 值の性能を用いた ${ }^{11}$ 。(3)木放じを多数本打ち付けた時の、最大耐力、 降伏耐力、寸べり係数の低減は起こらない。この仮定は別に行った
同等条件の多数本ビス打ち仕口の一面せん断試験結果を 2.2 の試験 結果と比較して得た。

先孔を空けない場合の木秝じせん断試験より得た木㸚じ一本の接 合部の完全弾塑性モデルにおいて、耐力壁の壁倍率の決定に関わる 4 因子を算出した。結果を表 3 に示寸。ここで示寸降伏荷重は完全 弾塑性モデルにより算出したものであり、以後 $P_{y-B L}$ と表記する。構 造特性係数 $D_{s}$ は塑性率 $\mu$ を用い、 $D_{s}=1 / \sqrt{2 \mu-1}$ とし、塑性率 $\mu$ は 完全弾塑性モデルの終局変位をその降伏点変位で除したものである

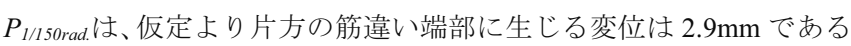
ので、完全弾塑性置換におけるすべり係数 $K$ に $2.9 \mathrm{~mm}$ を乗じた值と、 木ねじの降伏を考慮し終局荷重 $P_{u}$ の值のうち最小の值を用いた。ま た、表中の下限值は信頼性水準 $75 \%$ の 95\%下側許容限界值を示す。 $n$ 本の木ねじを用いた接合部の性状はこれらの数值の $n$ 倍とした。 筋違い耐力壁の上部にかかる水平荷重と筋違いの軸力との関係を幾 何学的に算定することで、壁倍率 3.0 に相当する水平せん断力を満 た寸木ねじ本数をそれぞれの因子において算出した。

異樹種 LVL を主材とするとき 4 因子のうち $P_{y-B L}$ が最も低い下限 值を示した。異樹種 LVL に比心゙、ベイマツ製材はばらつきが多いた め、 $P_{y-B L 、} P_{u} \times\left(0.2 / D_{s}\right) 、 P_{1 / 150 \mathrm{rad} .}$ の 3 つ条件で異樹種 LVL に劣っ ていた。ただし今回、壁の条件によらず、耐力壁試験の筋違い端部 で金物と筋違いを緊結する木ねじの本数は異樹種 LVL 材において 目標耐力を満足する最小本数である 10 本とした。

\section{4 片筋違い耐力壁試験}

図 11 に荷重一変形角曲線のそれぞれ条件で代表的なものを示す。こ こで示寸変形角は梁材の水平方向変位(図 7 : 変位計\#1)から土台の水 平方向変位(図 7 : 変位計\#2)を引いた值を試験体せいで除したもので あり、以後変形角はこの定義とする。異樹種 LVL とベイマツ製材の 両方で筋違いに圧縮荷重を受けて破壊した場合と、引張荷重を受け て破壊した場合を比較すると圧縮荷重を受けて破壊した場合の方が 最大荷重において高い值を示した。これは $1 / 60 \mathrm{rad}$. 以上変形してい る時には筋違い材が異樹種 LVL、ベイマツ製材ともにその端部が柱 一横架材に接触し、筋違い端部の圧縮抵抗により高い耐力を示した と考えられる。圧縮方向での破壊は異樹種 LVL、ベイマツ製材のい ずれも、最初に間柱が筋違いによる欠き込みされた箇所で曲げ破壊 が生じ、その直後に筋違いが座屈破壊を生じた。間柱の横架材に止 め付けた CN90 釘 2 本は引き抜けが生じた。

図 12 に各条件の包絡線と完全弾塑性モデルの平均を示す。また各 条件の壁倍率を決定する 4 つの要素と壁倍率を表 4 に示す。表 4 で 示した耐力壁の性能を評価する指標のうち、特に引張破壊・ベイマ ツ製材筋違いの条件における $P_{u} \times\left(0.2 / D_{s}\right)$ の項が他のものより低か った。写真 3 に見られるようにベイマツ製材を用いた試験体では、 筋違い材の端部に於いて木㸚じが繰り返し変形を受けることにより、 


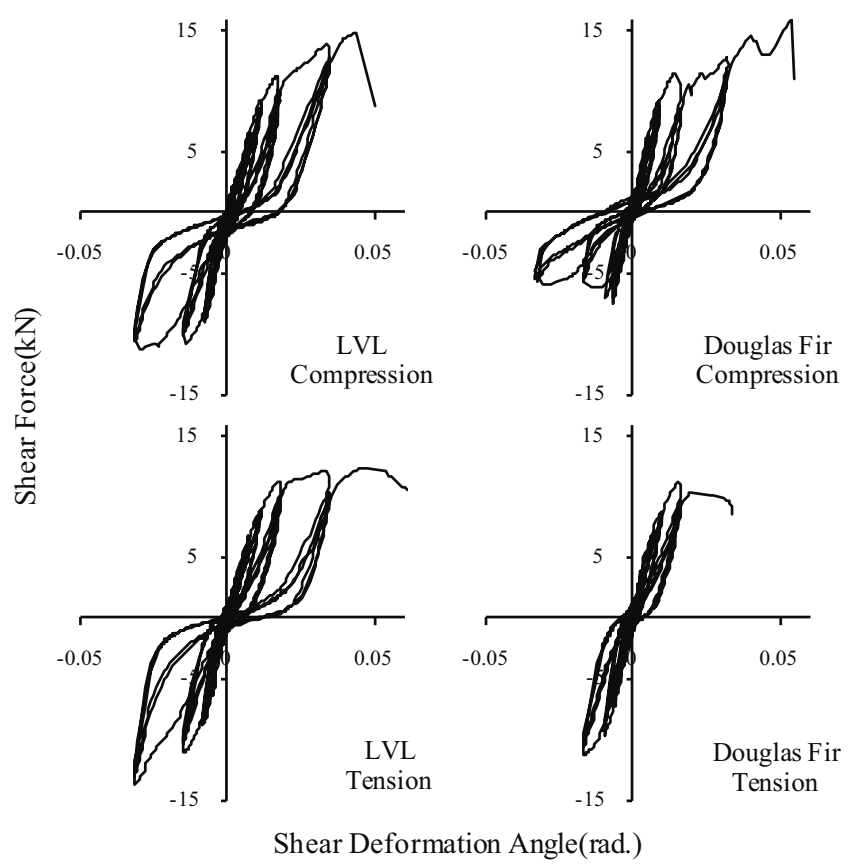

図 11 耐力壁試験：代表的荷重一変位曲線

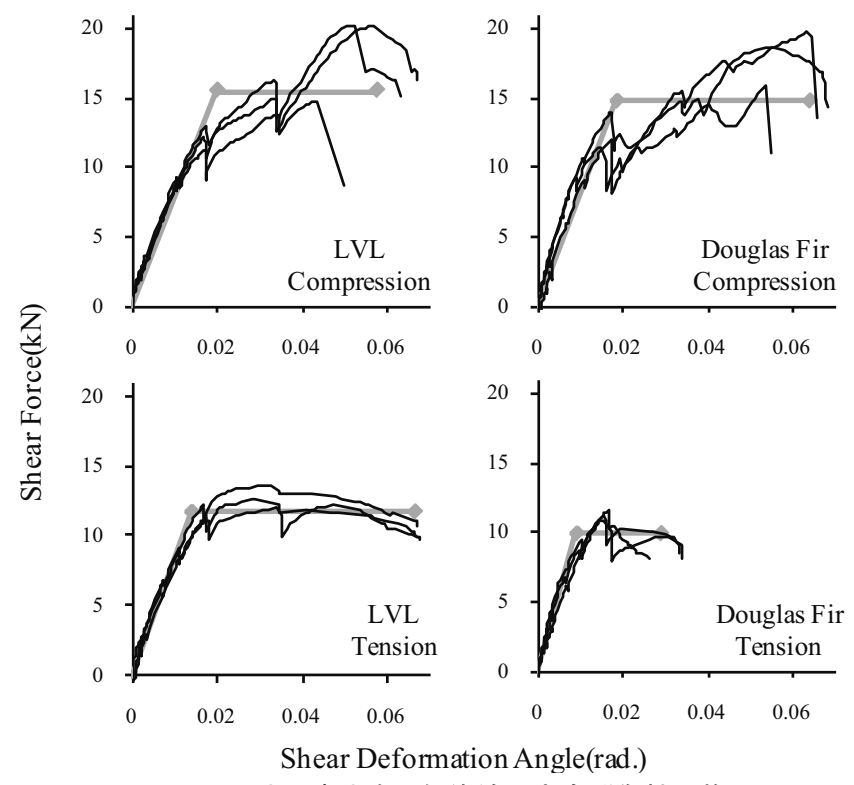

図 12 耐力壁試験：包絡線と完全弾塑性置換

小さな変形で割裂が生じたためと考えられる。写真 4 で示寸様に、 異樹種 LVL とベイマツ製材との間で圧縮により破壊した場合の筋 違いの破壊性状が異なった。今回の条件では圧縮方向に 1/60rad. 以

表 4 耐力壁試験結果：完全弾塑性置換における特性值と壁倍率
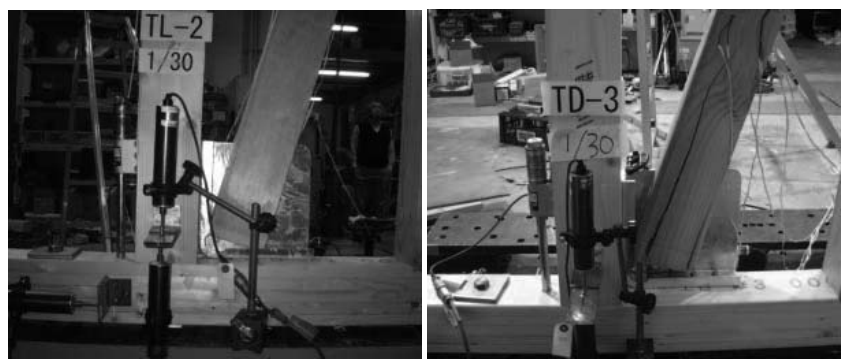

写真 3 1/30rad. 変形時における筋違い端部の様子 （左：異樹種 LVL、右：ベイマッ製材）
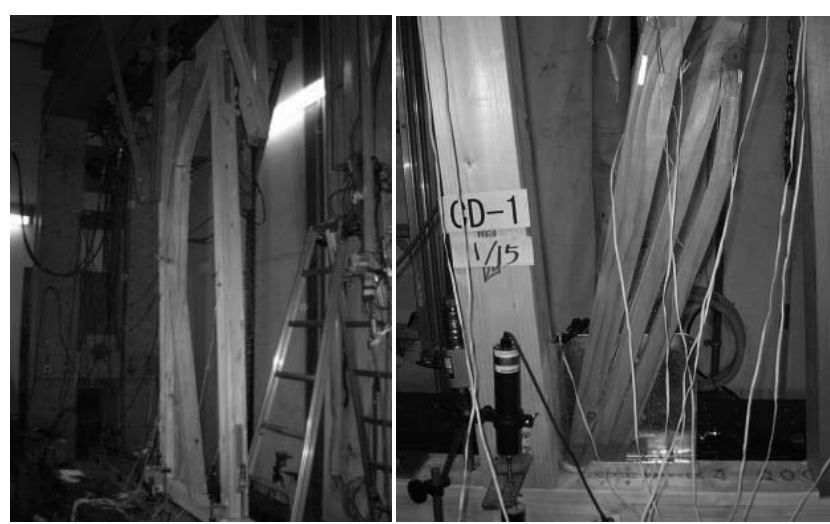

写真 4 筋違い材座屈破壊の様子

（左：異樹種 LVL、右：ベイマツ製材）

上の変形を受けた時に筋違い材が柱一横架材に金物を通して接触す る。その後筇違い材にかかる軸力が座屈荷重に達すると異樹種 LVL の場合、筋違い材は面外にはらんだ後座屈破壊を生じた一方、ベイ マツ製材では初期に発生した割裂破壊が進展し、写真 4 の右に示寸 ように筋違い端部に複数の不規則な割裂が生じて荷重が低下した。 よって、異樹種 LVL の筋違い材の圧縮荷重が作用寸る時、最大耐力 がベイマツ製材のそれに劣るのは、筋違い材としてのヤング係数が 異樹種 LVL の方が若干低かったため、座屈が先行して発生したもの と推察された。初期条件として筋違い材と金物との間でより大きな クリアランスを設けることで、破壊時変形量を増大させ壁倍率を引 き上げることが出来たと考えられる。

また、異樹種 LVL、ベイマツ製材でそれぞれ $P_{1 / 150 \mathrm{rad}}$ が圧縮、引 張の時でほぼ同等な耐力を発揮した。初期段階で筋違いとフレーム とが接触することを防ぎ、筋違い耐力壁の耐力が木ねじの抵抗のみ によって発現している結果だと考えられる。

壁倍率は全ての条件において $P_{u} \times\left(0.2 / D_{s}\right)$ によって決まった。べイ マツ製材の場合、圧縮の壁倍率が 3.9 であるが、引張時の壁倍率は 2.3 と大きく異なっているのに対し、異樹種 LVL を筋違い材に用い

\begin{tabular}{|c|c|c|c|c|c|c|c|c|c|c|c|c|}
\hline & \multicolumn{6}{|c|}{ LVL } & \multicolumn{6}{|c|}{ Douglas Fir } \\
\hline & \multicolumn{3}{|c|}{ Compression } & \multicolumn{3}{|c|}{ Tension } & \multicolumn{3}{|c|}{ Compression } & \multicolumn{3}{|c|}{ Tension } \\
\hline & Ave.(kN) & C.V.(\%) & E.V.(kN) & Ave. $(\mathrm{kN})$ & C.V. $(\%)$ & E.V.(kN) & Ave. $(\mathrm{kN})$ & C.V. $(\%)$ & E.V.(kN) & Ave. $(\mathrm{kN})$ & C.V.(\%) & E.V.(kN) \\
\hline$\overline{P P_{y-B L}}$ & 10.8 & 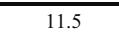 & 10.2 & $\overline{77.7}$ & 186.4 & 7.1 & 11.1 & 12.5 & 10.4 & $\overline{c 6.2}$ & 8.7 & $\overline{5.9}$ \\
\hline$P_{u} \times\left(0.2 / D_{s}\right)$ & 6.8 & 18.9 & 6.2 & 7.0 & 5.9 & 6.8 & 7.3 & 11.3 & 6.9 & 4.7 & 26.9 & 4.1 \\
\hline $2 / 3 P_{\max }$ & 12.2 & 17.0 & 11.3 & 8.5 & 5.3 & 8.3 & 12.0 & 10.8 & 11.4 & 7.5 & 3.0 & 7.3 \\
\hline$P_{1 / 150 \text { rad }}$ & 7.7 & 3.1 & 7.6 & 7.2 & 6.1 & 7.0 & 8.0 & 11.4 & 7.6 & 8.0 & 7.7 & 7.8 \\
\hline SRF & & 3.5 & & & 3.8 & & & 3.9 & & & 2.3 & \\
\hline Determinant on SRF & & ${ }_{u} \times(0.2 / D$ & & & $D_{u} \times\left(0.2 / D_{s}\right.$ & & & ${ }_{u} \times(0.2 / D$ & & & ${ }_{u} \times(0.2 / D$ & \\
\hline
\end{tabular}

(注)SRF:壁倍率 
た場合、その壁倍率は僅かに引張時の性能が高いとはいえ、引張時 と圧縮時ともに 3.0 を超えた。

\section{4. まとめ}

ラバーウッド/ファルカータ異樹種 LVL の筋違い材としての各種 力学性能の評価と異樹種 LVL を主材とした木対じのせん断試験を 行った結果、異樹種 LVL を筋違い材として用いた時、この LVLの ばらつきが少なく、かつ積層効果を併せ持つことから、筋違い端部 の接合性能のばらつきを抑えることができることを確認した。また、 木ねじ一本あたりのせん断性能から壁倍率 3.0 の性能を有する筋違 い耐力壁を実現させるために必要となる筋違い端部に必要な木ねじ の本数を求め、この本数の木対じで筋違い端部を施工した耐力壁の 実大試験を行ったところ、その壁倍率は筋違い材に引張荷重が作用 する時と圧縮荷重が作用する時でともに 3.0 を超え、かつ引張と圧 縮との差はベイマツ製材を筋違い材として用いた時に生じる差より も小さかった。このことから筋違い材に圧縮荷重が作用寸る時と引 張荷重が作用する時とで同等で、かつ合板耐力壁を上回る壁倍率 3.0 以上の高い性能を持つ片筋違い耐力壁を開発できた。

\section{5. 謝辞}

本研究の一部は H19 年度 JST イノベーションプラザ京都・可能性 試験(実用化検討)研究予算により行いました。また、試験を行うに あたり(株)ユニウッドコーポレーションより異樹種 LVL 試験体の提 供を、中国木材(株)よりベイマツ製材の提供を受けました。併せて、 本研究を進めるにあたり、在籍する研究室の諸先輩、後輩達から多 くの助言、助力をいただきました。

本紙面をお借りして、御支援に対し厚く御礼申しあげます。

\section{引用・参考文献}

1) (株)ユニウッドコーポレーション:横尾國治, 増田稔, 村田功二:積層複 合木質材执よびその製造方法,特願 2003-537885,2005

2 ) 村田功二,増田稔,横尾國治:ラバーウッド/ファルカータ交互積層による LVL の反りの緩和とその膨潤挙動の観察,木材学会誌,50(5), 294-300,2004

3 ）村田功二,小薮洋,中野降人:交錯積層が単板積層材の面圧試験の破壊形 態に与える影響,材料, $57(4), 322-327,2008$

4）日本規格協会:木材の試験方法,JIS Z2101,2002

5) ASTM Intl.: Standard Test method for Evaluating Dowel-Bearing Strength of Wood and Wood-Based Products, D 5764-97a, 2002

6 ）西山誕生,安藤直人:ロープ効果を考慮したボル卜接合部の 2 面せん断特 性の予測 幾何学的非線形解析の適用,木材学会誌,49(5),355-364,2003

7 ）日本規格協会:冷間圧造用炭素鋼一第一部:線材,JIS G3507-1,2005

8）日本規格協会:金属製品熱処理用語,JIS B6905,1995

9) EN1995-1-1:2004(E): Eurocode 5 Design of timber structure,2004

10 ）日本建築学会編:木質構造設計規準・同解説,pp279-285,369-371, 日本建 築学会,2006

11 ） 日本住宅・木材技術センタ一編:木造軸組工法住宅の許容応力度設計, pp565-578,日本住宅・木材技術センター,2008

12 ) 平嶋義彦、金谷紀行、畑山義男、神谷文夫 : 筋違入り軸組の剪断性能 とその構造解析 (第二報) 軸組の構造解析,木材学会誌,27(12), $855-862,1981$

[2008 年 10 月 20 日原稿受理 2008 年 12 月 25 日採用決定 $]$ 